\title{
Isolated Klippel-Feil syndrome
}

INSERM

\section{Source}

INSERM. (1999). Orphanet: an online rare disease and orphan drug data base. Isolated Klippel-Feil syndrome. ORPHA:2345

Klippel-Feil Syndrome is characterised by improper segmentation of cervical segments resulting in cong enitally fused cervical vertebrae. 